the great phyla, not on the recognition and retention, parrot-like, of minute differences between species. Often it will be found that such families practically correspond with the genera such as Ostrea, Pecten and Rhynchonella, for which Dr. Rastall has such a nostalgic sentiment, and here he is fighting the air, for teachers of palæontology have long since complied with the spirit of his plea.

Alan Wood.

Imperial College of Science and Technology,

$$
\text { London, S.W.7. }
$$

1 NatURe, 151, 294 (1943).

ON a minor point the two foregoing letters are contradictory. Dr. Wood says a field geologist can name his own fossils, while Prof. Trueman admits that he cannot. Only a palæontologist can decide this.

Dr. Wood's remarks on granite are really irrelevant. If, instead of basalt and granite, names chosen as known to everybody, I had written, for example, "umptekite Ramsay" and "jocupirangite Derby", his argument would have no bearing on the subject.

I can assure Prof. Trueman that my article was meant to be taken very seriously. I do not suggest that the decline of geology as an academic subject and a popular hobby is due solely to pedantry, but generally to the crushing burden of a complioated nomenclature. As an example of pedantry, which is near akin to priggishness, I instanced the habit of quoting the authority for a fossil every time. If space allowed, I could quote a scathing paragraph on this subject written in 1899 by Prof. Charles Lapworth. Only the last sentence can be given here. "Such vain repetition can only add unnecessarily to the amount of the printer's bills, and increase what is amply sufficient for scientific purposes, the vanity of the species maker himself."

The main object of my article was to protest against the incessant multiplication of new generic names founded usually on minute differences and obscuring genetic relationships. This I regard as obscurantist and anti-evolutionary. A French physicist has well written, "Nature is a workshop, not $a$ museum", and the object of research should be to discover her methods and her tools. But palæontology has now become a chaotic mass of disconnected names. To paraphrase a famous saying of Henri Poincaré, a card index is not a science, any more than a dictionary is a language.

R. H. Rastall.

\section{Mode of Chemical Action of X-Rays on a Non-Aqueous Solution}

DALE, Meredith and Tweedie ${ }^{1}$ have recently shown that the mode of action of X-rays on certain dissolved enzymes, similarly to the action on aqueous ferrosulphate $^{2}$ and on aqueous hrmoglobin ${ }^{3}$, is in agreement with the 'indirect action' mechanism ${ }^{3}$ as opposed to the 'direct hit' mechanism. It appears that the ionizing radiation activates the water and that the activation products in turn react with the enzyme. Hydrogen peroxide has previously been identified as one product of the irradiation of water ${ }^{4}$.

It may be interesting to compare the results of Dale et al. with those of some (unpublished) experiments in non-aqueous solution, which were carried out at the Institute of Physical Chemistry, University of Berlin, during 1931-32, but could not be completed owing to the political changes in Germany. The object was to show whether what is now called the 'direct hit' mechanism applies to solutions of X-ray sensitive substances in non-sensitive solvents, that is, in solvents which, when used alone, are not activated. In such solvents radiation energy would not be stored. 'Direct hit' reactions should be of the first order both with regard to X-ray dosage and to concentration ; on the other hand, the rates of reactions of the type described by Dale et al. can in extreme cases be independent of concentration.

First an attempt was made to measure the decomposition in organic solvents of benzophenone diazide $\left(\mathrm{C}_{6} \mathrm{H}_{5}\right)_{2} \mathrm{C}\left(\mathrm{N}_{3}\right)_{2}$, a substance previously studied as a solid $^{5}$. Unfortunately, the nitrogen liberated in the solution could not be measured with any accuracy owing to supersaturation. However, success was achieved with a solution of ammonium persulphate in practically anhydrous glycerine. The solution was contained in a cylindrical glass tube $2 \mathrm{~cm}$. long and $1 \mathrm{~cm}$. wide (volume very nearly 1.5 c.c.) which was mounted in a fixed position about $2 \mathrm{~cm}$. from the window of the $\mathrm{X}$-ray tube. The rays were produced in a gas tube with molybdenum anticathode, filtered through zirconium oxide and aluminium, and had an effective wave-length of $0.8 \mathrm{~A}$. They entered the glass vessel through its extremely thin concave base ${ }^{6}$. The concentrations before and after irradiation were determined iodometrically. Glycerine by itself was not affected. In a preliminary run it was ascertained that at constant concentration the yield is proportional to dosage, if irradiation was interrupted before the concentration decreased markedly.

In the accompanying table concentrations are given in mgm./c.c. and dosages in arbitrary relative units, each unit representing $1 \mathrm{~m}$-amp.-hour; voltage (40 kV.) was kept constant. The variation with increasing concentration of the absorbing and scattering properties of the solutions will not materially change the energy available.

$\begin{array}{cccc}\text { Concentration } & \text { Dosage } & \begin{array}{c}\text { Mgm. } \\ \text { decomposed }\end{array} & \begin{array}{c}\text { Percentage decreases } \\ \text { per unit dosage }\end{array} \\ 109 & 67 & 2 \cdot 5 & 0 \cdot 023 \\ 150 & 51 & 2 \cdot 5 & 0 \cdot 022 \\ 190 & 87 & 3 \cdot 3 & 0 \cdot 013 \\ 263 & 70 & 6 \cdot 8 & 0 \cdot 025 \\ 381 & 68 & 7 \cdot 8 & 0 \cdot 020 \\ 382 & 81 & 9 \cdot 8 & 0 \cdot 021 \\ \text { Solid } & >100 & 0 & 0\end{array}$

The constancy of the last column shows that in the range investigated the yield per dosage unit is proportional to concentration; that is, the reaction is of the first order with regard to persulphate concentration. The lack of effect on the solid seems to show that the decomposition proceeds in several stages and that a medium is required to prevent reformation of ammonium persulphate from a primary product.

While the results of Fricke and of Dale et al. indicate that in aqueous tissues yields are generally less than proportional to concentration, the above experiment demonstrates that this need not be so in non-aqueous (for example, lipoidal) tissue.

This work was undertaken on the initiative of Prof. P. Günther, who devoted much attention to it.

Cavendish Laboratory, E. BRODA. Cambridge.

${ }^{2}$ Dale, W. M., Meredith, W. J., and Tweedie, M. C. K., NATURE, 151 280 (1943).

aricke, H., and Morse, S., Phil. Mag., 7, 129 (1929).

3 Fricke, H., Cold Spring Harb. Sympos., 2, 241 (1934).

- Risse, O., Z. physik. Chem., A, 140, 133 (1929); Risse, O., Fortschr Röntgenstr., 46,62 (1932).

5 Götzky, S., Günther, P., and Cronheim, G., Strahlentherapie, 43 379 (1932)

- Colvert, W. W., Phys. Rev., 36, 1619 (1930). 